\title{
基于足底压力下㬹闭眼对静态平衡功能的影响
}

\author{
林 强 ${ }^{1,2}$, 陈武德 ${ }^{2}$, 郑显欣 ${ }^{1,2}$, 廖婉晨 ${ }^{2}$, 黄海东 ${ }^{2}$, 欧海宁 ${ }^{1,2}$, 梁俊杰 ${ }^{1,2^{*}}$ \\ 1 广州医科大学附属第五医院, 广东广州 510700 ; \\ 2 广州医科大学, 广东广州 511436 \\ *通信作者:梁俊杰,E-mail:ljj88961@gzhmu.edu.cn
}

收稿日期: 2020-06-13; 接受日期: 2020-07-29

基金项目:国家自然科学基金青年科学基金项目 (81902281); 广东省普通高校青年创新人才类项目 (2019KQNCX119); 广州市卫生健康科技项目 (20191A011091、20201A011108); 广州医科大学大学生科技创新项目 (2019A057)

DOI : 10.3724/SP.J.1329.2021.01003

开放科学(资源服务)标识码 (OSID)：

摘要目的: 采用足底压力分析技术对正常年轻人的睁眼、闭眼状态下的姿势控制进行评估, 旨在研究视觉 输入对于静态平衡功能的影响。方法: 选取 66 例健康成年人作为研究对象, 指示受试者站立于 FreeMed 足 底压力分析测试板固定位置。测试者按前、后、左、右 4 个方向摆动受试者骨盆, 使受试者双脚压力均匀分 布。先后进行睁眼和闭眼状态监测, 分别记录足底压力数据 $30 \mathrm{~s}$ 。使用 Freestep 足底压力分析系统对已采集 足底压力原始数据进行预处理, 得出球长度、椭圆面积、平均嗃度、平均 $\mathrm{X}$ 、平均 $\mathrm{Y}$ 、槠圆倾斜角、梢圆偏心 角、最大摆动、最小摆动和左右双侧下肢的足底整体负荷、前足负荷和后足负荷。结果: 在睁眼和闭眼 2 种状 态下受试者的椭圆面积 $(P<0.05)$ 、平均 $\mathrm{Y}(P<0.001)$ 和最大摆动 $(P<0.001)$ 的差异均有统计学意义。对比㬹 眼状态, 闭眼时正常人的梢圆面积减小, 平均 $Y$ 减小, 而最大摆动增加。根据足底压力中心 $(\mathrm{COP})$ 的散点图 分布情况, 发现睁眼状态下 COP 分布较闭眼状态下集中。对比睁眼和闭眼 2 种状态, 受试者的左脚前足负荷 $(P<0.001)$ 、右脚前足负荷 $(P<0.001)$ 、左脚后足负荷 $(P<0.001)$ 和右脚后足负荷 $(P<0.001)$ 的差异均有统计 学意义。闭眼状态较琤眼状态下左脚前足负荷和右脚前足负荷均有增加, 而左脚后足负荷和右脚后足负荷 均有减少。在左侧下肢与右侧下肢 2 种状态对比中, 受试者的琤眼状态左脚整体负荷较右侧下肢减少 $(P=$ $0.030)$; 在闭眼状态下左脚整体负荷也比右侧下肢减少 $(P=0.021)$, 差异有统计学意义。由前足和后足在琤闭 眼 2 种状态的对比中可见, 受试者的后足负荷均明显大于前足负荷 $(P<0.001)$, 差异有统计学意义。结论: 视 觉输入作用于椭圆面积和濹动幅度, 影响静态平衡功能维持; 本研究通过足底压力分析的运动学和动力学 参数量化评估平衡功能, 力求能为临床评估提供方向。

关键词足底压力; 静态平衡; 足底压力中心; 运动学; 动力学

平衡是维持身体稳定性的一种能力, 贯穿于人 类的日常活动 ${ }^{[1]}$ 。平衡控制主要是由前庭感受器、视 觉感受器和本体感受器提供外周感觉信息, 然后传 人中枢神经系统进行信息加工、整合, 最后通过视 觉定位和运动控制调控人体重心位置 ${ }^{[2]}$ 。其中, 视觉 输人是影响平衡控制的重要因素, 有研究显示视觉 输人可用于改善对姿势的控制, 从而达到平衡训练 的目的 ${ }^{[3]}$ 。站立位姿势调整, 有赖于足部运动控制,
但足部是通过何种机制对平衡功能进行控制, 视觉 输人与足部调控之间存在何种联系, 前人研究仍未 有明确结论 ${ }^{[4]}$ 。因此, 本研究通过足底压力分析, 期 望能从运动学和动力学 2 种参数阐述视觉输人对 于静态平衡功能的影响。

足底压力分析是否能应用于平衡功能评估? 现 阶段平衡功能评估, 主要以临床评估量表的定性评 估和平衡功能测定系统的定量评估为主, 如 Berg 平

引用格式:林强,陈武德,郑显欣, 等. 基于足底压力下琤闭眼对静态平衡功能的影响 [J]. 康复学报,2021,31(1):17-23.

LIN Q, CHEN W D, ZHENG Y X, et al. Effect of eyes open/closed on plantar pressure during static balance evaluation [J]. Rehabilitation Medicine,2021, 31(1): 17-23.

DOI : $10.3724 /$ SP.J.1329.2021.01003 
衡量表、起立-步行测试、Pro-kin 平衡系统、Tertrax 平衡测试系统等 ${ }^{[1,5]}$ 。近年来随着足底压力 (plantar pressure) 系统的推广应用, 国外有研究将其用于平 衡功能的定量分析 ${ }^{[2,6-11]}$, 但在国内仍较少报道。因 此, 本实验希望能验证足底压力分析能否应用于平衡 功能评估, 采用足底压力分析技术对健康年轻人的 睁眼、闭眼状态下的姿势控制进行评估。

\section{1 对象与方法}

\section{1 研究对象}

本实验招募健康年轻人 80 例, 男女比例为 $1: 1$ 。 纳人标准: (1) 年龄 18 30 岁; (2) 身体健康, 运动功 能正常; (3) 否认引起平衡异常的相关病史, 如脑血. 管病、多发性硬化、双下肢骨折、下肢疼痛、长短腿、 关节炎等疾病; (4) 否认正在使用影响平衡功能的药 物; (5) 自愿签署知情同意书。该实验已通过广州医: 科大学附属第五医院伦理会审查 (伦理批件号为 KY01-2019-06-20)。

\section{2 足底压力分析}

\subsection{1 测试前准备}

1.2.1.1 房间准备 需准备安静的房间, 防止外界 因素干扰。足底压力分析测试板放置于距离空白墙 壁约 $1.5 \mathrm{~m}$ 处, 墙上有一可调节高度的红色 “+”标示 物, 大小约 $10 \mathrm{~cm} \times 10 \mathrm{~cm}$, 根据受试者高度调整位 置, 使其与受试者眼睛持平, 减少头部对实验结果 影响。

1.2.1.2 设备准备 实验设备为 FreeMed 足底压力 分析测试板 (SensorMedica, 意大利), 传感面积为 $1600 \mathrm{~mm} \times 400 \mathrm{~mm}$, 传感器密度为 4 个 $/ \mathrm{cm}^{2}$, 传感 器数量为 25600 个。测试前需提前对足底压力信 号接收板进行表面清理,防止上面细小杂物对测试 结果造成影响。足底压力分析测试板中央粘贴站立 足印标识, 引导受试者站立于相同位置, 确保检测 结果可靠。

1.2.1.3 受试者准备 受试者测试前 1 天及当天避 免进行剧烈活动, 以减少对实验的影响。测试时需 赤脚, 并完全暴露踝关节。在测试开始前嘱咐受试 者在测力台上活动 $5 \mathrm{~min}$ 左右, 以适应环境并减缓 紧张情绪, 避免因精神性因素影响实验结果。

\subsection{2 测试开始}

(1) 启动测试设备和电脑, 输人受试者基本信息, 包括年龄、性别、出生日期、身高、体质量、利手、文 化程度。(2) 指示受试者站立于测力台中央标示位 置, 双脚平放对称, 双手自然垂于身体两侧。测试者
待受试者站稳后, 按前、后、左、右 4 个方向摆动受 试者骨盆, 使受试者双脚压力均匀分布, 并判断受 试者站姿是否端正, 询问受试者站立是否舒适, 必要 时再次摆动骨盆。(3) 睁眼状态监测: 采集睁眼状态 足底压力数据, 调整红色 “+”标示物位置, 使其与受 试者眼睛持平,指示受试者目视正前方 $1.5 \mathrm{~m}$ 处“+”, 待受试者正常自然站稳后, 开始记录足底压力数据 $30 \mathrm{~s}$ 。(4) 闭眼状态监测: 采集闭眼状态足底压力数 据, 指示受试者闭眼, 经过 $5 \mathrm{~s}$ 左右稳定期后, 开始 记录足底压力数据 $30 \mathrm{~s}$ 。(5) 数据采集并不告知受试 者, 减少因声音刺激或紧张等因素影响实验数据。 实验全程由另一名测试者于受试者背后进行保护, 避免跌倒事件发生。

\subsection{3 足底压力数据处理}

使用 Freestep 足底压力分析系统对已采集足底 压力原始数据进行预处理。数据主要分为运动学参 数和动力学参数 2 种。运动学参数包括球长度、椭 圆面积、平均速度、平均 $\mathrm{X}$ 、平均 $\mathrm{Y}$ 、椭圆倾斜角、椭 圆偏心角、最大摆动和最小摆动; 动力学参数包括 左右双侧下肢的足底整体负荷、前足负荷和后足负 荷。足底压力中心 (center of pressure, COP) 通过 X 轴和 Y 轴数据进行定位。见图 1。

\section{3 统计学方法}

采用 SPSS 22.0 软件进行统计分析, Excel 绘制 散点图。所有计量资料首先进行数据预处理, 求出 均数和标准差, 通过 Excel 管选出超过标准差 3 倍 的高度异常值, 高度异常值超过 $20 \%$ 的受试者数 据将排除出组; 接, 着进行正态性检验, 服从正态分 布采用配对 $t$ 检验, 偏态分布则采用Wilcoxon 秩和 检验。以 $P<0.05$ 表示差异具有统计学意义。

\section{2 结果}

\section{1 一般资料}

招募健康年轻人 80 例, 经数据预处理排除后, 剩余 66 例为有效研究对象, 其中男 33 例, 女 33 例; 平均年龄 $(20.63 \pm 0.89)$ 岁; 平均体质量 $(45.21 \pm$ $8.04) \mathrm{kg}$; 右利手 65 例, 左利手 1 例。

\section{2 睁眼和闭眼状态下运动学参数比较}

在睁眼和闭眼 2 种状态下受试者的椭圆面积 $(P=0.016<0.05)$ 、平均 $\mathrm{Y}(P<0.001)$ 和最大摆动 $(P<0.001)$ 的差异均有统计学意义。对比睁眼状态, 闭眼时正常人的椭圆面积减小, 平均 $\mathrm{Y}$ 减小, 而最 大摆动增加。见表 1 。 

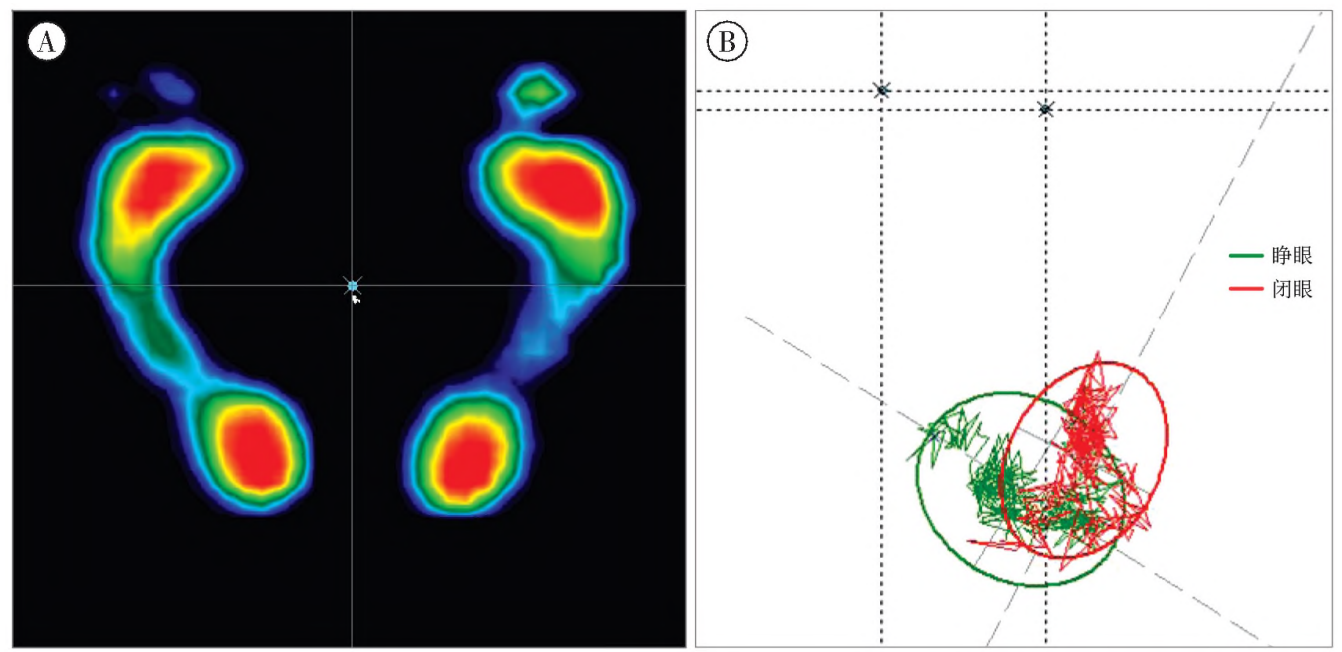

注: A. 受试者双侧足底压力负荷图; B. 睁眼和闭眼 2 种状态下重心移动轨迹示意图,包括球长度、椭圆面积、 $\mathrm{X}$ 轴、 $\mathrm{Y}$ 轴等。

Note: A. Pressure load of the subject's bilateral planters; B. Center of gravity movement trajectory during eyes open and closed.

图 1 足底压力分析系统结果示意图

Figure 1 Diagram of the results of the plantar pressure analysis

表 1 睁眼和闭眼状态下运动学参数比较

Table 1 Comparison of kinematic parameters when eyes opened and closed

\begin{tabular}{lcccr}
\hline \multicolumn{1}{c}{ 项 目 } & 睁眼 $(\bar{x} \pm s)$ & 闭眼 $(\bar{x} \pm s)$ & $t$ 值 $/ Z$ 值 & -0.78 \\
\hline 球长度 $/ \mathrm{mm}$ & $198.58^{1)}$ & $214.07^{1>}$ & -2.40 & 0.438 \\
椭圆面积 $/ \mathrm{cm}^{2}$ & $33.54^{1)}$ & $25.39^{1)}$ & -0.24 & 0.016 \\
平均速度 $/(\mathrm{mm} / \mathrm{s})$ & $21.72 \pm 7.42$ & $21.25^{1)}$ & -0.41 & 0.813 \\
平均 $\mathrm{X} / \mathrm{mm}$ & $4.19 \pm 6.04$ & $4.33 \pm 6.66$ & -4.73 & 0.684 \\
平均 $\mathrm{Y} / \mathrm{mm}$ & $-22.43 \pm 10.98$ & $-20.24^{1)}$ & -1.26 & $<0.001$ \\
椭圆倾斜角 $/{ }^{\circ}$ & $107.00^{1)}$ & $73.00^{1)}$ & -0.95 & 0.210 \\
椭圆偏心角 $/{ }^{\circ}$ & $0.45^{1)}$ & $0.50^{1)}$ & -4.03 & 0.343 \\
最大摆动 $/ \mathrm{mm}$ & $2.59 \pm 0.82$ & $3.06^{1)}$ & -0.82 & $<0.001$ \\
最小摆动 $/ \mathrm{mm}$ & $0.03^{1)}$ & $0.03^{1)}$ & 0.412 \\
\hline
\end{tabular}

注: 1 ) 为非正态分布数据, 以 Median 表示。

Notes: 1) presents abnormal distribution data which expressed in Median.

\section{3 睁眼和闭眼状态下 COP 的比较}

通过软件计算受试者于测试期间足底压力中 心在 $\mathrm{X}$ 轴和 $\mathrm{Y}$ 轴中的平均距离, 得出结果为平均 $\mathrm{X}$ 和平均 $\mathrm{Y}$, 进一步定位 $\mathrm{COP}^{[12]}$ 。根据 $\mathrm{COP}$ 的散点图 分布情况, 发现睁眼状态下 COP 分布较闭眼状态下 集中。见图 2。

\section{4 睁眼和闭眼状态下左右侧足底压力分布参数} 比较

对比睁眼和闭眼 2 种状态, 受试者的左脚前足 负荷、右脚前足负荷、左脚后足负荷和右脚后足负 荷差异均有统计学意义 $(P<0.001)$ 。闭眼状态较睁 眼状态下左脚前足负荷和右脚前足负荷均有增加，
而左脚后足负荷和右脚后足负荷均有减少。见表 2 。 2.5 双侧下肢在睁眼和闭眼状态下足底压力分布 参数比较

在左侧下肢与右侧下肢 2 种状态对比中, 受试 者的睁眼状态左脚整体负荷较右侧下肢减少 $(P=$ $0.030)$; 在闭眼状态下左脚整体负荷也比右侧下肢 减少 $(P=0.021)$, 差异有统计学意义。见表 3 。

2.6 前足和后足在睁眼和闭眼状态下足底压力分 布参数比较

由前足和后足在琤闭眼 2 种状态的对比中可 见, 受试者的后足负荷均明显大于前足负荷 $(P<$ 0.001 ), 差异有统计学意义。见表 4 。 


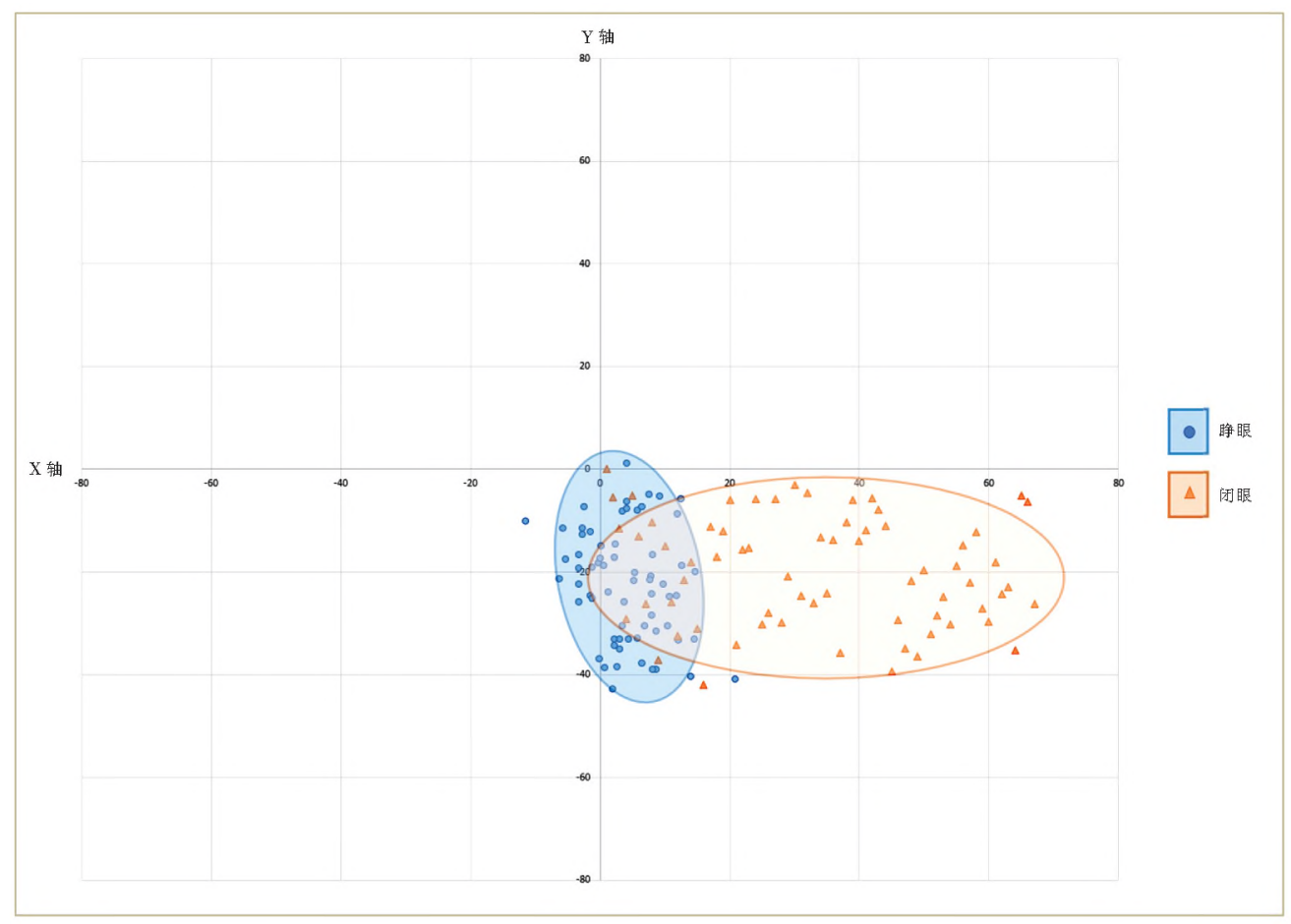

图 2 睁眼和闭眼状态下 COP 的分布示意图

Figure 2 Diagram of the distribution of COP during eyes open and closed

表 2 睁眼和闭眼状态下足底压力分布参数比较

Table 2 Comparison of the plantar pressure distribution parameters when eyes open and closed

\begin{tabular}{|c|c|c|c|c|c|}
\hline 项 目 & 位置 & 睁眼 $(\bar{x} \pm s, \%)$ & 闭眼 $(\bar{x} \pm s, \%)$ & $t$ 值 $/ Z$ 值 & $P$ 值 \\
\hline \multirow{2}{*}{ 整体负荷 } & 左脚 & $48.88 \pm 3.86$ & $48.83 \pm 3.99$ & 0.24 & 0.809 \\
\hline & 右脚 & $51.00^{1)}$ & $51.17 \pm 3.99$ & -0.52 & 0.603 \\
\hline \multirow{2}{*}{ 前足负荷 } & 左脚 & $40.74 \pm 9.15$ & $42.02 \pm 9.22$ & -3.72 & $<0.001$ \\
\hline & 右脚 & $40.67 \pm 10.30$ & $42.65 \pm 10.13$ & -4.94 & $<0.001$ \\
\hline \multirow{2}{*}{ 后足负荷 } & 左脚 & $59.26 \pm 9.15$ & $57.98 \pm 9.22$ & 3.72 & $<0.001$ \\
\hline & 右脚 & $59.14 \pm 10.38$ & $57.50 \pm 10.33$ & 4.19 & $<0.001$ \\
\hline
\end{tabular}

注:1)为非正态分布数据, 以 Median 表示。

Notes: 1) presents abnormal distribution data which expressed in Median.

表 3 左脚和右脚足底压力分布参数比较

Table 3 Comparison of the plantar pressure distribution parameters on left and right side

\begin{tabular}{|c|c|c|c|c|c|}
\hline 项 目 & 状态 & 左脚 $(\bar{x} \pm s, \%)$ & 右脚 $(\bar{x} \pm s, \%)$ & $t$ 值 $/ Z$ 值 & $P$ 值 \\
\hline \multirow{2}{*}{ 整体负荷 } & 睁眼 & $48.88 \pm 3.86$ & $51.00^{1)}$ & -2.18 & 0.030 \\
\hline & 闭眼 & $48.83 \pm 3.99$ & $51.17 \pm 3.99$ & -2.38 & 0.021 \\
\hline \multirow{2}{*}{ 前足负荷 } & 睁眼 & $40.74 \pm 9.15$ & $40.67 \pm 10.30$ & 0.07 & 0.942 \\
\hline & 闭眼 & $42.02 \pm 9.22$ & $42.65 \pm 10.13$ & -0.66 & 0.513 \\
\hline \multirow{2}{*}{ 后足负荷 } & 睁眼 & $59.26 \pm 9.15$ & $59.14 \pm 10.38$ & 0.12 & 0.906 \\
\hline & 闭眼 & $57.98 \pm 9.22$ & $57.50 \pm 10.33$ & 0.50 & 0.623 \\
\hline
\end{tabular}

注:1)为非正态分布数据, 以 Median 表示。

Notes: 1) presents abnormal distribution data which expressed in Median. 
表 4 前足和后足压力分布参数比较

Table 4 Comparison of the pressure distribution parameters between forefoot and hindfoot

\begin{tabular}{cccccc}
\hline 项目 & 状态 & $\begin{array}{c}\text { 前足负荷 } \\
(\bar{x} \pm s, \%)\end{array}$ & $\begin{array}{c}\text { 后足负荷 } \\
(\bar{x} \pm s, \%)\end{array}$ & $t$ 值 & $P$ 值 \\
\hline \multirow{2}{*}{ 左脚 } & 睁眼 & $40.74 \pm 9.15$ & $59.26 \pm 9.15$ & -8.22 & $<0.001$ \\
& 闭眼 & $42.02 \pm 9.22$ & $57.98 \pm 9.22$ & -7.03 & $<0.001$ \\
\multirow{2}{*}{ 右脚 } & 睁眼 & $40.67 \pm 10.30$ & $59.14 \pm 10.38$ & -5.72 & $<0.001$ \\
& 闭眼 & $42.65 \pm 10.13$ & $57.50 \pm 10.33$ & -5.91 & $<0.001$ \\
\hline
\end{tabular}

\section{3 讨 论}

平衡控制主要取决于视觉、前庭和本体感觉 3 个 要素, 必须整合这 3 个要素, 并与运动和认知系统 结合才能维持身体的稳定 ${ }^{[13-15]}$ 。感觉输人是维持人 体平衡的重要参与环节。正常人在睁眼状态下站 立,下肢本体感觉输人和视觉输人对平衡调控起关 键作用; 闭眼状态时, 则前庭系统代替视觉输人, 通 过测知头部的位置及运动, 使身体各部适当调整从

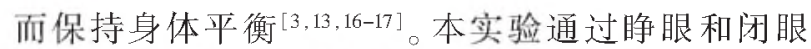
2 种状态模拟视觉剥夺, 但是足底接触面和体位并 未改变,排除对本体感觉和前庭系统产生不稳定影 响, 单纯讨论视觉对于平衡功能的影响; 结合足底 压力分析技术, 从运动学和动力学 2 个方面探究视 党输人对于正常年轻人平衡功能的影响。

\section{1 睁眼和闭眼状态下运动学参数变化}

椭圆面积由 $\mathrm{X}$ 轴和 $\mathrm{Y}$ 轴数据计算得出, $\mathrm{COP}$ 由 $X$ 轴和 $Y$ 轴定位得出, 这些参数的变化与足底压 力分析中感应的重心活动相关, 反映平衡功能维持 与调整的程度。本实验中可见正常年轻人在睁眼状 态下椭圆面积比闭眼状态下稍增大, 差异具有统计 学意义, 但是差异程度较小; 另外, 睁眼状态下平均 $\mathrm{Y}$ 也比闭眼状态下大, 说明 $\mathrm{COP}$ 在 $\mathrm{Y}$ 轴上移动更 明显, 提示正常年轻人在睁眼状态下摆动幅度更大, 且主要以前后摆动为主。值得注意的是, 虽然睁眼 状态下椭圆面积较大, 但是结合 COP 散点图可见, 正常年轻人在睁眼状态下的 COP 相对集中, 闭眼状 态下 $\mathrm{COP}$ 明显分散。考虑以上结果可能与睁眼测试 时视觉注视点引起的视觉输人相关。然而对于正常 老年人及儿童的研究结果与本实验相反。PARK ${ }^{[18]}$ 采用足底压力分析, 研究正常老年人睁闭眼下 COP 的变化,结果提示闭眼下 COP 摆动幅度高于睁眼状 态。正常儿童闭眼状态的身体抎动面积、 $X$ 轴、 $Y$ 轴 和 COP 均大于睁眼状态 ${ }^{[13]}$ 。另外, 本实验同时记录 摆动幅度的最大值和最小值, 结果显示睁眼状态下
的最大摆动比闭眼时小, 提示睁眼状态下的摆动幅 度小, 可能摆动幅度比椭圆面积对于平衡稳定性的 相关性更高。

\section{2 睁眼和闭眼状态下动力学参数变化}

本实验中采用的动力学参数主要为双侧足底 负荷百分比(均一化处理后的足底负荷), 并进一步 分为前足负荷和后足负荷。本实验前足和后足负荷 比较, 结果表明正常年轻人静态站立时主要以后足 负重为主, 这与前人研究结果吻合 ${ }^{[19]}$ 。同时, 实验结 果显示, 琤眼状态下双侧下肢的前足负荷均较闭眼 状态时明显减少, 后足负荷较闭眼状态明显增加。 正常年轻人在睁眼站立时出现前一后方向活动趋 势, 符合运动学相关结果; 而闭眼站立时, 出现前倾 趋势, 重心前移, 后足负荷相应减少。睁闭眼状态下 前后足负荷的改变, 可能与注视点的视觉刺激呈现 的方向相关, 提示视觉输人在静态平衡控制方面存 在一定调节作用, 且视觉刺激的方向可能为影响因 素之一。在睁闭眼状态下, 双侧下肢整体负荷未有 明显差异, 说明左侧和右侧下肢负重并不受琤闭眼 状态影响; 但左右侧下肢之间存在差异, 右侧下肢 负重大于左侧下肢, 这可能与优势侧肢体相关。实 验结果提示, 正常年轻人通过改变前后足负重分布 调控平衡能力, 可能与视觉刺激相关。

\section{3 视觉对于平衡的影响}

视觉反馈属于平衡功能控制的一个重要影响 因素。本实验结果可见, 在睁眼状态站立时, 正常年 轻人通过前后足负重比例调整, 进而使 $\mathrm{COP}$ 在 Y 轴 (前一后方向) 上出现变化; 在闭眼状态下, 视觉被剥 夺, 前后足负重比例和 COP 在 Y 轴方向出现相应调 整, 这与 HOFFMAN 等 ${ }^{[20]}$ 研究结果相一致, 即视觉 反馈在前一后方向的平衡调整中是最明显的。除此 之外, 闭眼时躯干的最大摆动增加, 可能是在去除 视觉反馈后, 通过不断调整躯干和 COP 以维持身体 平衡。

\section{4 基于足底压力分析技术对平衡功能的评佔}

足底压力分析作为一种常见的下肢评估工具, 多用于步态评估、鞋垫制作、足部疾病诊断等, 而通 过足底压力分析对平衡功能进行客观评估研究在 国内仍较少见。INOJOSA 等 ${ }^{[21]}$ 采用睁闭眼平衡检测 手段对多发性硬化患者进行评估, 主要指标为运动 学参数中的平均抎动范围、平均速度和平均抎动速 度, 结果提示多发性硬化患者比正常人更依赖视觉 反馈来保持婆势控制。另外, 目前国内对于平衡功 能评估仍以半定量评估方式为主, 而采用运动学和 
动力学数据评估平衡功能, 能更客观、准确定量评 估平衡能力。杨伟等 ${ }^{[22]}$ 采用 BALANCE 平衡训练系 统对脑卒中患者进行平衡功能评估, 通过 $\mathrm{COP}$ 和 $\mathrm{COP}$ 运动轨迹客观评估平衡能力。李墨逸等 ${ }^{[23]}$ 使用 Prokin 平衡训练系统对正常人进行评估, 能有效观察 正常人经八段锦训练前后平衡相关指标的变化。 HOWCROFT 等 ${ }^{[24]}$ 采用测力台结合睁闭眼方案评估 老年人跌倒风险, 主要监测指标为 $\mathrm{COP}$ 运动范围和 速度,研究结果表明准确率达 $84.9 \%$, 证明该评估方 式切实可行。FRANZONI 等 ${ }^{[25]}$ 采用与测力台和睁闭 眼方案有效评估帕金森患者的静态平衡功能,说明 该方案可应用于异常平衡功能评估。前人研究与本 实验结果均以睁闭眼平衡检测作为评估方案, 关键 指标以 COP、运动范围和足底压力负荷分布为主, 可作为睁闭眼平衡测试方案重点关注指标, 提供一 种可用于临床评估平衡功能障碍的客观方案。

\section{4 总 结}

综上所述, 本实验结果如下: (1) 健康年轻人通 过改变前后足负重比例分布进而实现不同视觉输 人状态下对平衡功能的调控; (2) 通过足底压力分析 的运动学和动力学参数可用于静态平衡功能定量 化评估。本实验验证了视觉刺激对于健康年轻人平 衡功能的影响, 是否能通过加强视觉反馈对平衡功 能进行强化需要今后进一步研究; 另外, 本实验提 供了一种使用足底压力分析客观评价平衡功能的 方式,可应用于视觉相关平衡能力的评估, 且该方 法简单易行, 下一步研究可考虑应用于病理性平衡 功能障碍患者, 为足底压力分析用于临床客观、定 量评估平衡功能提供一种新思路。

\section{参考文献}

[1] LIN Y, NIE M E, WANG L. Advancement of balance function assessment for stroke patients (review) $[\mathrm{J}]$. Chin J Rehabil Theory Pract, 2016, 22(6):667-671.

林源, 钮美娥, 王雨。脑卒中患者平衡功能评定方法的应用 进展 $[\mathrm{J}]$. 中国康复理论与实践, 2016,22(6):667-71.

[2] GERMANO A M,SCHMIDT D, MILANI T L. Effects of hypothermically reduced plantar skin inputs on anticipatory and compensatory balance responses [J]. BMC Neurosci, 2016,17(1):41.

[3] PELLEGRINO L, GIANNONI P, MARINELLi L, et al. Effects of continuous visual feedback during sitting balance training in chronic stroke survivors [J]. J Neuroeng Rehabil, 2017, 14(1):107.

[4] GIAGAZOGLOU P, AMIRIDIS I G,ZAFEIRIDIS A, et al. Static balance control and lower limb strength in blind and sighted women [J]. Eur J Appl Physiol, 2009, 107 (5) : 571-579.

[5] LIN Q,ZHENG Y, LIAN P, et al. Quantitative static and dynamic assessment of balance control in stroke patients $[\mathrm{J}]$. J Vis Exp, 2020(159). doi : 10.3791/60884.

[6] DIBAI-FILHO A V,DE JESUS GUIRRO R R, REZENDE M S, et al. Analysis of peak plantar pressure and center of pressure oscillation in individuals with chronic neck pain: A cross-sectional study $[\mathrm{J}]$. J Back Musculoskelet Rehabil , 2017,30(6): $1259-1264$

[7] EMA R, SAITO M, OHKI S,et al. Association between rapid force production by the plantar flexors and balance performance in elderly men and women $[\mathrm{J}]$. Age (Dordr), 2016,38(5/6): $475-483$.

[8] HAMED A,BOHM S,MERSMANN F, et al. Exercises of dynamic stability under unstable conditions increase muscle strength and balance ability in the elderly [J]. Scand J Med Sci Sports,2018, $28(3): 961-971$.

[9] PARSONS S L, MANSFIELD A, INNESS E L, et al. The relationship of plantar cutaneous sensation and standing balance post-stroke [J]. Top Stroke Rehabil, 2016,23(5):326-332.

[10] HOWCROFT J,LEMAIRE E D, KOFMAN J, et al. Understanding responses to gait instability from plantar pressure measurement and the relationship to balance and mobility in lower-limb amputees [J]. Clin Biomech (Bristol, Avon), 2016, 32:241-248.

[11] SENDUR S N, OGUZ S, DAGDELEN S, et al. Assessment of static and dynamic plantar data of patients with acromegaly $[\mathrm{J}]$. Pituitary, 2019,22(4):373-380.

[12] BICKLEY C, LINTON J, SULLIVAN E, et al. Comparison of simultaneous static standing balance data on a pressure mat and force plate in typical children and in children with cerebral palsy [J]. Gait Posture, 2019,67:91-98.

[13] DA SILVA PONTES L, CALLEGARI B, MAGNO L, et al. Variations in plantar pressure and balance in HIV-infected children in antiretroviral therapy $[\mathrm{J}]$. Sci Rep, $2019,9(1): 4344$.

[14] KILBY M C, MOLENAAR P C,SLOBOUNOV S M, et al. Realtime visual feedback of COM and COP motion properties differentially modifies postural control structures $[\mathrm{J}]$. Exp Brain Res, 2017, 235 (1): 109-120.

[15] TAKEDA K, MANI H, HASEGAWA N, et al. Adaptation effects in static postural control by providing simultaneous visual feedback of center of pressure and center of gravity [J]. J Physiol Anthropol , 2017,36(1):31.

[16] DOS ANJOS F, LEMOS T, IMBIRIBA L A. Does the type of visual feedback information change the control of standing balance? [J]. Eur J Appl Physiol, 2016,116(9):1771-1779.

[17] KIM M K, LEE J C, YOO K T. The effects of shoulder stabilization exercises and pectoralis minor stretching on balance and maximal shoulder muscle strength of healthy young adults with round shoulder posture [J]. J Phys Ther Sci, 2018,30(3): 373-380.

[18] PARK J H. The effects of plantar perception training on balance and falls efficacy of the elderly with a history of falls:A single-blind, randomized controlled trial $[\mathrm{J}]$. Arch Gerontol Geriatr, $2018,77: 19-23$.

[19] DE PAUla Lima P O, CAMELO P R P, FERREIRA V, et al. 
Evaluation of the isokinetic muscle function, postural control and plantar pressure distribution in capoeira players:a crosssectional study [J]. Muscles Ligaments Tendons J, 2017, 7(3): $498-503$

[20] HUFFMAN J L,NORTON L E, ADKIN A L, et al. Directional effects of biofeedback on trunk sway during stance tasks in healthy young adults $[\mathrm{J}]$. Gait Posture, 2010,32(1):62-66.

[21] INOJOSA H,SCHRIEFER D, TRENTZSCH K, et al. Visual feedback and postural control in multiple sclerosis $[\mathrm{J}]$. J Clin Med, $2020,9(5): 1291$.

[22] YANG W, WANG H, XU F Y, et al. Effect of BALANCE evaluation and training system on early trunk control ability of patients with cerebral apoplexy $[\mathrm{J}]$. Rehabil Med, 2017,27(2): $17-21$.
杨伟, 王红, 徐洋凡, 等. BALANCE 评定与训练系统对脑卒中 患者早期躯干控制能力疗效观察 $[\mathrm{J}]$. 康复学报, 2017,27(2): $17-21$.

[23] LI M Y, LAN X L, YAN X H, et al. Effect of health Qing-Baduanjin on the balance function of college students $[\mathrm{J}]$. Rehabil Med, 2015, 25(1):14-18.

李墨逸, 蓝秀芦, 鄢行辉, 等. “健身气功・八段锦”对大学生 平衡功能的影响 $[\mathrm{J}]$. 康复学报, 2015,25(1):14-18.

[24] HOWCROFT J,LEMAIRE E D, KOFMAN J, et al. Elderly fall risk prediction using static posturography $[\mathrm{J}]$. PLoS One,2017, 12(2): e0172398.

[25] FRANZONI L T, MONTEIRO E P, OLIVEIRA H B, et al. A 9week nordic and free walking improve postural balance in Parkinson's disease [J]. Sports Med Int Open, 2018,2(2):E28-E34.

\title{
Effect of Eyes Open/Closed on Plantar Pressure during Static Balance Evaluation
}

\author{
LIN Qiang ${ }^{1,2}$, CHEN Wude ${ }^{2}$, ZHENG Yuxin ${ }^{1,2}$, LIAO Wanchen ${ }^{2}$, HUANG Haidong ${ }^{2}$, OU Haining ${ }^{1,2}$, LIANG Junjie I, $^{1 *}$ \\ ${ }^{1}$ The Fifth Affiliated Hospital of Guangzhou Medical University, Guangzhou, Guangdong 510700, China; \\ ${ }^{2}$ Guamgzhou Medical University, Guangzhou, Guangdong 511436, China \\ *Correspondence: LIANG Junjie, E-mail: 1jj88961@gzhmu.edu.cn
}

\begin{abstract}
Objective: To evaluate the effect of visual input on static balance function, by assessing the posture control of young healthy subjects with eyes open and closed using the plantar pressure analysis technique. Methods: A total of sixty-six young, healthy adults were recruited in the study. They were instructed to stand at a fixed position on the FreeMed plantar pressure analysis test board. The subject's pelvis was swung in four directions including front, back, left and right, to make their foot pressure evenly distributed. The pressure data of the soles was recorded in eyes open and closed states for 30 seconds, respectively. The collected data was processed using the Freestep plantar pressure analysis system. The ball length, ellipse area, average velocity, average X, average Y, ellipse tilt angle, ellipse eccentricity, maximum swing, minimum swing, and total plantar load, forefoot load, and hind foot load of the left and right lower limbs were obtained. Results: There were significant differences in the ellipse area $(P<0.05)$, the average $\mathrm{Y}(P<0.001)$ and the maximum swing $(P<0.001)$ of the subjects in the two states of eyes open and closed. Compared with eyes open condition, the ellipse area decreased, the average $Y$ decreased, and the maximum swing increased during eyes closed condition. According to the scatter plot distribution of center of pressure (COP), it was found that the COP distribution was more concentrated with the eyes open than that with eyes closed. Comparing the two conditions (eyes open and eyes closed), the subjects' left foot forefoot load $(P<0.001)$, right foot forefoot load $(P<0.001)$, left foot hind foot load $(P<0.001)$ and right foot hind foot load $(P<0.001)$ were significantly different. Compared with the eyes open, the left-foot forefoot load and the right-foot forefoot load increased both, while the left-foot hind foot load and the right-foot hind foot load decreased. In the comparison of the two status of the left lower limb and the right lower limb, the subject's overall load on the left foot in the eyes open state was reduced compared with the right lower limb $(P=0.030)$; the overall load on the left foot was also lower than that on the right side in eyes closed. The difference of the lower limbs decreased was statistically significant $(P=0.021)$. In the comparison of the forefoot and hind foot in eyes open and closed, the hind foot load was significantly greater than the forefoot load $(P<0.001)$. Conclusion: The findings of this experiment indicated that normal young subjects could adjust the balance function under different visual input status by changing the ellipse area and swing amplitude. The kinematics and dynamics parameters analyzed by plantar pressure analysis can be used for quantitative and clinical evaluation of static balance function.

KEY WORDS plantar pressure; static balance; plantar pressure center; kinematics, dynamics
\end{abstract}

DOI: $10.3724 /$ SP.J.1329.2021.01003 